\title{
MIMICRY OF FISH LARVAE LIVE FOOD WITH PARTICLES OBTAINED BY IONIC GELATION AND COATED WITH PROTEINS THROUGH ELECTROSTATIC INTERACTION
}

\author{
JULIANA BÜRGER RODRIGUES* \\ FERNANDO TELLO* \\ NATALIA DE JESUS LEITÃO** \\ MARIA CÉLIA PORTELLA*** \\ CARLOS RAIMUNDO FERREIRA GROSSO****
}

\begin{abstract}
In an attempt to mimic the proximate composition found in Artemia's nauplii, a type of food commonly used in intensive rearing of fish larvae, inert diets were produced by ionic gelation using either low methoxyl amidated pectin or sodium alginate and subsequently coated with whey proteins by electrostatic interaction. The particles were morphologically characterized by optical microscopy and scanning electron microscopy, showing spherical shape when moist or rehydrated. The resulting particles were characterized according to their proximate composition, average size, and rehydration behavior after freeze drying. The coated pectin and alginate particles, had sizes averaging $256.7 \mu \mathrm{m} \pm 17.1$ and $241.9 \mu \mathrm{m} \pm 7.5$, respectively, with no statistical difference. In relation to the contents of lipid, protein, drymatter, and ash, the resulting particles were similar to the live food. However, an in vivo evaluation with fish larvae becomes necessary to confirm their suitability and functionality.
\end{abstract}

KEY-WORDS: IONIC GELATION; ELECTROSTATIC INTERACTION; PECTIN; ALGINATE; WHEY PROTEIN; MICROPARTICLES.

* Doutorandos em Controle de Qualidade, Departamento de Alimentos e Nutrição, Faculdade de Engenharia de Alimentos (FEA), Universidade Estadual de Campinas (UNICAMP), Campinas, SP (e-mail: xuburger@ fea.unicamp.br; fcelis@fea.unicamp.br).

** Doutoranda em Zootecnia, Universidade Estadual de São Paulo (USP), Jaboticabal, SP (e-mail: nati_ leitao@yahoo.com.br).

*** PhD em Aquicultura, Professor, Centro de Aquicultura, USP, Jaboticabal, SP (e-mail: portella@caunesp. unesp.br).

**** PhD em Ciência de Alimentos, Professor, Departamento de Alimentos e Nutrição, FEA, UNICAMP, Campinas, SP (e-mail: grosso@fea.unicamp.br). 


\section{INTRODUCTION}

The encapsulation technology is a delivery method that allows the controlled release of ingredients under specific conditions, such as heating, hydration, diffusion, mechanical pressure and biodegradation (PEPPAS \& BRANNON-PEPPAS, 1996; ANAL \& STEVENS, 2005; KAILASAPATHY \& MASONDOLE, 2005).

Currently, the encapsulation is used in different areas including pharmaceutical and food industries. In the food industry, it can be used as a protection against environmental adversity conditions (temperature, pH, light, moisture), to improve stability of flavors, enzymes, microorganisms, vitamins, fatty acids, minerals and peptides, and as well as to mask undesirable taste (DZIEZAK, 1988; LISERRE, RÉ \& FRANCO, 2007). Furthermore, microencapsulation have being used for incorporating bioactive compounds in fortified foods (AUGUSTIN et al., 2011).

Microencapsulation has also being investigated for the substitution or reduction of live food, such as rotifers, and Artemia, commonly used in larviculture (LANGDON, 2003). The inert micro diets have the ability to provide a full diet to the larva, preventing nutrient loss and deterioration of water tanks, among others. However, despite these positive characteristics, microencapsulated diets developed for feeding fish larvae, have yielded low growth and low survival rates (HAMLIN \& KLING, 2001). Many authors related this fact to the low acceptance, assimilation and digestion of these diets, both of which are directly related to the intrinsic nature of the particle, such as texture, taste, color, design, size, density and stability in water (CAHU \& ZAMBONINO INFANTE, 2001; KOLKOVSKI, 2001). The Artemia nauplii is generally composed of $9.2 \%$ dry matter and $55-60 \%$ of protein in dry basis (BASKERVILLE \& KLING, 2000). However, most micro diet developed as live food replacement with adequate levels of protein also contain high amounts of dry matter (> $90 \%$ ) (BASKERVILLE \& KLING, 2000; GUTHRIE et al., 2000).

Alginate and pectin are examples of natural polymers, non-toxic, biodegradable and biocompatible (CHAN, LEE \& HENG, 2002). They are used in microencapsulation processes for biomedical applications, and also for the production of diets for feeding fish larvae (GUTHRIE et al., 2000). Ionic gelation is used in particles production; it happens under mild conditions, it is low cost, simple, and fast. It involves an aqueous polymer solution, which when in contact with low molecular mass ions, interacts forming a complex. Alginate and low methoxyl pectin are widely used as wall materials, and the calcium ion is the most used reticulation agent. The electrostatic characteristics, and the gels formation make these polysaccharides good wall source material for the particles formation (MESTDAGH \& AXELOS, 1998).

Despite these positive characteristics, the ionic gelled particles are generally very porous, and possess low holding capacity when compared to other techniques for encapsulating water soluble compounds of low molecular mass (MUKAI-CORREA et al., 2004). To work around this problem it is possible to associate the ionic gelation, and the complex coacervation techniques, which besides improving the porosity and release of encapsulated hydrophilic material, allows greater protein retention. By adding a polycation (proteins or chitosan) to the particle obtained by ionic gelation, it is possible to induce the formation of polyanionic-polycationic complex stabilizing the hydrogel network; thus reducing the permeability of the alginate or pectin particles, and improving the chemical and mechanical stability of the same particles (HUGUET \& DELLACHERIE, 1996; ALLAN-WOJTAS et al., 1999; CHANDRAMOULI et al., 2004; DAI, WANG \& ZHAO, 2005). Gbassi et al. (2011) combined the ionic gelation with alginate, and covered the particles with whey protein by complex coacervation, to produce gastric protection to the encapsulated microorganisms.

In this study, the objective was to produce diets that mimic live food (Artemia franciscana) commonly used in intensive larviculture, through ionic gelation using low methoxyl amidated pectin or alginate with high guluronic acid content, and subsequently coated with whey protein through electrostatic interaction. The particles were characterized for the proximate composition, morphology, swelling and the average size. Additionally, the polysaccharides and protein solutions 
were evaluated with respect to the zeta potential at different $\mathrm{pH}$ values.

\section{MATERIAL AND METHODS}

\subsection{MATERIAL}

The following materials were used: sodium alginate (AG) DMB (high molecular mass, high content of guluronic groups (lot G3512301 MANUGEL, FMC Biopolymer, Brazil), citrus pectin, low methoxyl amidated pectin - LMAP (CPKelco, mixture of different lots, Limeira, São Paulo, Brazil), galacturonic acid (GA) $85.9 \% \pm 1.9$, degree of esterification (DE) $34.1 \% \pm 1.3$ and degree of amidation (DA) $5.5 \% \pm 0.4$ as determined (FAO, 2009), whey protein concentrate - WPC (Lacprodan, lote Lac804U17601, 76, Porteña, Província de Córdoba, Argentina; moisture content $6.9 \pm 0.1 \%$; protein content $81.0 \pm 1.0$; ash content $2.77 \pm 0.06$ and lipids content $16.2 \pm 0.5$ determined according to AOAC, 2006, anhydrous calcium chloride P.A. (Dinâmica, lot 36308, P.M. 110.99), cold pressed sunflower oil (Viapaxbio, Joinville, Santa Catarina, Brazil), vitamin and mineral mixture (Fri-Ribe, Pitangueiras, Brazil), according to the manufacturer, containing the following amounts per $100 \mathrm{~g}$ of the mixture: folic acid $1 \mathrm{mg}$, pantothenic acid $20 \mathrm{mg}$, BHT antioxidant $125 \mathrm{mg}$, choline $150 \mathrm{mg}$, copper $10 \mathrm{mg}$, iron $100 \mathrm{mg}$, iodine $5 \mathrm{mg}$, manganese $70 \mathrm{mg}$, selenium $0.15 \mathrm{mg}$, vitamin A $3000 \mathrm{Ul}^{.} \mathrm{kg}^{-1}$, vitamin B1 $6 \mathrm{mg}$, vitamin B12 $20 \mathrm{mg}$, vitamin B2 $8 \mathrm{mg}$, vitamin B6 $3 \mathrm{mg}$, vitamin C $350 \mathrm{mg}$, vitamin D3 3000 Ul. $\mathrm{kg}^{-1}$, vitamin E $200 \mathrm{mg}$, vitamin K $6 \mathrm{mg}$, zinc $150 \mathrm{mg}$, niacin $100 \mathrm{mg}$, biotin $0.10 \mathrm{mg}$ ), and other analytical grade reagents.

\subsection{ZETA POTENTIAL OF THE MATERIALS}

The determination of the zeta potential of the WPC, LMAP and GA solutions $(0.1 \% \mathrm{w} / \mathrm{w})$, was carried out using a Zetasizer (Malvern, Worcestershire, UK) in the 3-7 pH ranges. Measurements were independently prepared for two samples. Duplicate readings were performed for each sample, and the results expressed as means \pm standard deviation (SOUZA et al. 2012).

\subsection{PRODUCTION OF PARTICLES}

The particles were prepared with a solution of LMAP or alginate $(2 \% \mathrm{w} / \mathrm{w}$ of the total emulsion) emulsified with sunflower oil (25\% w/w total solids) and vitamin and mineral complex (4.5\% w/w total solids) using an Ultra Turrax homogenizer (IKA, Brazil) at $14.000 \mathrm{rpm} / 3 \mathrm{~min}$. The emulsion was sprayed with a double fluid atomizer (diameters 1.0 and $1.5 \mathrm{~mm}$ for pectin and alginate, respectively) with compressed air flow $\left(0.125\right.$ and $0.375 \mathrm{kgf} / \mathrm{cm}^{2}$ of pectin and alginate, respectively), positioned at $12 \mathrm{~cm}$ from the calcium chloride solution level $(2 \% \mathrm{w} / \mathrm{w}, \mathrm{pH} 4.0)$ under constant magnetic stirring. For the full gelation, the particles were held for 30 min (curing time) in a calcium chloride solution. After the curing time, the particles were washed in sieves with water adjusted to $\mathrm{pH} 4.0(\phi=125 \mu \mathrm{m})$, and dispersed in solutions of non-denatured WPC (12\% w/w, pH 4.0) under constant magnetic stirring for $30 \mathrm{~min}$. The particles were again transferred to sieves $(\phi$ $=125 \mathrm{~mm}$ ) and washed with water adjusted to $\mathrm{pH} 4.0$ (SOUZA et al., 2012). The moisture content was determined for both, the PEM particles (particles produced with pectin) and the ALM particles (particles produced with alginate) and covered with whey proteins. The adsorbed protein levels were also determined, after the deduction of the LMAP nitrogen content. Then, the particles were dried in a freeze dryer (Edwards Pirani 501 West Sussex, UK). The temperature was reduced to $-40^{\circ} \mathrm{C}$, under pressure of $0.1 \mathrm{mmHg}$. The final drying was performed at $25^{\circ} \mathrm{C}$ temperature. The dried material was packed in lidded jars, and stored at $-18^{\circ} \mathrm{C}$. The particles were produce in nine independent batches. After drying out, the batches were mixed and characterized. 


\subsection{CHARACTERIZATION OF THE PARTICLES}

\subsubsection{Proximate composition}

Moist particles, were characterized in regard to the protein, moisture and ash contents, according to AOAC (2006); and lipids according Bligh \& Dyer (1959). A preliminary digestion of the protein adsorbed on the particle was needed for the determination of lipid content, allowing for a complete lipid extraction, because of its retention in the protein fraction. Sodium citrate solution $(2 \% \mathrm{w} / \mathrm{w})$ was added to $5 \mathrm{~g}$ of moist particles, to allow the dissolution of the particles. Then $0.3 \mathrm{mg}$ of pepsin/g was added, the $\mathrm{pH}$ corrected to 3.0 , stirred for $1 \mathrm{~min}$, and maintained in water bath $\left(37^{\circ} \mathrm{C}\right.$ ) with agitation for $4 \mathrm{~h}$. The $\mathrm{pH}$ was corrected to 7.0 , and $0.3 \mathrm{mg} / \mathrm{g}$ of pancreatin was added, stirred for $1 \mathrm{~min}$, and maintained in bath $\left(37^{\circ} \mathrm{C}\right)$ for $12 \mathrm{~h}$. Following these steps, the extraction followed the Bligh \& Dyer methodology (1959).

\subsubsection{Average size and size distribution}

The average size ( $\mathrm{d} 0.5$ ) of moist and rehydrated particles at $\mathrm{pH} 7.0$, were determined using a Mastersizer 2000 (Malvern, Worcestershire, UK). With fast stirring, the dry particles were rehydrated with water $(\mathrm{pH} 7.0)$, and immediately followed by the size determination (SOUZA et al., 2012).

\subsubsection{Morphology}

The morphology of both, moist and rehydrated particles $(\mathrm{pH} 7.0)$ was observed by optical microscopy (Jenaval, Carl Zeiss, Germany). The images were captured with digital camera, fitted with 12.5 objectives, 1.25-x optvar and the EDN-2 program - Image Processing Microscopy System (SOUZA et al., 2012). The freeze dried particles microstructure was observed in a scanning electron microscope (SEM) Jeol T300 (Tokyo, Japan) using $15 \mathrm{kV}$. The samples were previously fixed on stubs with double-sided metallic tape and coated with a thin gold layer (40 mA/150 s) employing a Baltzer SCD50 evaporator (Baltec, Liechtensten).

\section{RESULTS AND DISCUSSION}

\subsection{ZETA POTENTIAL OF THE BIOPOLYMERS}

The zeta potential determines the amount of free charge in polysaccharides, and whey protein solutions; thus affording the assessment not only of a possible electrostatic interaction between the biopolymers but also of the $\mathrm{pH}$ range liable to contain the highest interaction. As expected, the zeta potential of the pectin and the alginate solutions (Figure 1) had a negative charge in the studied $\mathrm{pH}$ range; probably, because the low methoxyl amidated pectin presents a pKa of 2.9, as reported in the literature (RALET et al., 2001) and above this $\mathrm{pH}$, the polysaccharide solution will be negatively charged. Conversely, the alginate contains a pKa from 3.2 to 3.6; below these values, there is suppression of the carboxylic dissociation (SIMSEK-EGE, BOND \& STRINGER, 2003). Furthermore, the alginate presented higher levels of negative charge in relation to the pectin.

The $\mathrm{pH}$ chosen for the particles' production was adjusted to 4.0, as described previously in the literature, when beet pectin and $\beta$-lactoglobulin were used for nanoparticles production by electrostatic interaction (SANTIPANICHWONG et al., 2008). The choice of $\mathrm{pH}$ is justified because the isoelectric point ( $\mathrm{pl}$ ) found to whey proteins was of approximately 4.5 (Figure 1); thus, indicating that at $\mathrm{pH}$ levels below 4.5 and above 2.9 and 3.2 it is possible to achieve electrostatic interaction between the protein and polysaccharides. In connection with the whey protein, the isoelectric point (pl) reported before in the literature for the $\beta$-lactoglobulin, the major protein in whey, varies from 4.5 to 5.2 (WALKENSTRÖM \& HERMANSSON, 1997; LY et al., 2008) and at pH lower than the pl, the protein solution will be positively charged as shown in Figure 1. 


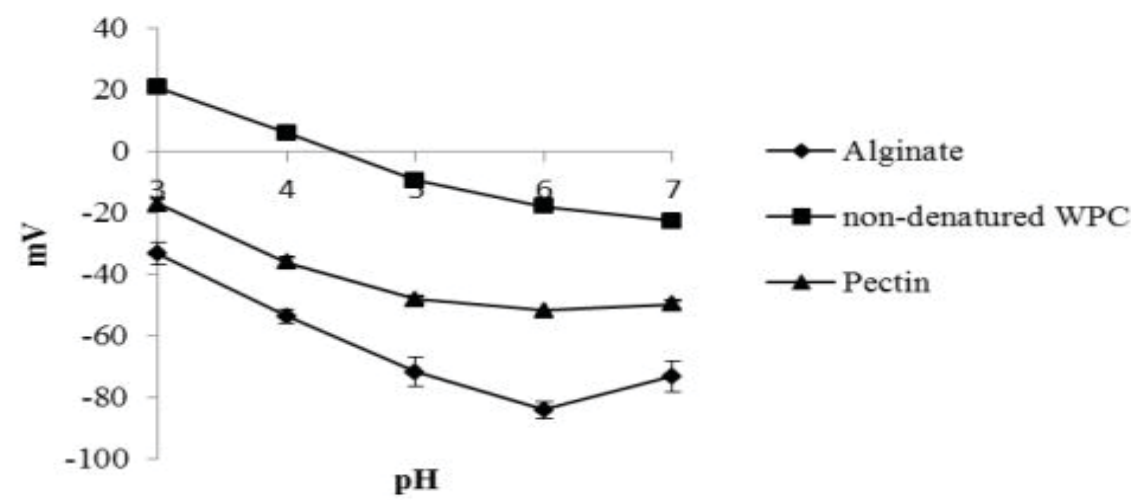

FIGURE 1 - THE pH EFFECT ON THE ELECTRIC CHARGE (Z POTENTIAL, $\mathrm{mV}$ ) OF THE SOLUTIONS (0.1\% w/w) OF PECTIN, ALGINATE, AND NON-DENATURED WPC

\subsection{PARTICLE SIZES}

Table 1 shows the mean diameters ( $\mathrm{d} 0.5$ ) of moist and rehydrated particles determined by light scattering using a Mastersizer meter.

TABLE 1 - MEAN DIAMETER $(\mu \mathrm{m})$ AND STANDARD DEVIATION OF PARTICLES, OBTAINED BY IONIC GELATION CONTAINING PROTEIN ADSORBED BY ELECTROSTATIC INTERACTION, MOIST AND REHYDRATED (pH 7.0)

\begin{tabular}{lcc}
\hline Treatments & Moist size & Rehydrated size \\
\hline PEM & $256.7 \pm 17.1^{\mathrm{A}^{*}}$ & $227.3 \pm 16.2^{\mathrm{aB}}$ \\
ALM & $241.9 \pm 7.5^{\mathrm{aA}}$ & $221.9 \pm 16.4^{\mathrm{aB}}$ \\
\hline
\end{tabular}

PEM = particles produced from pectin and covered with WPC; ALM = particles produced from alginate and covered with WPC*. Means followed by same letters (uppercase in the column and lowercase on the line) did not differ according to the Tukey test $(p>0.05)$.

The particle sizes obtained by ionic gelation using polymers, i.e., pectin or alginate, are affected by various parameters such as the diameter of the atomizer's needle, solution concentration, distance between the needle and the cationic solution (GOMBOTZ \& WEE, 1998; SILVA et al., 2006).

The particle average sizes obtained when pectin was used were: $243.3 \mu \mathrm{m} \pm 9.3$ for the uncoated moist particle and $256.7 \mu \mathrm{m} \pm 17.1$ for the coated particles. When using alginate, the values were $230.7 \mu \mathrm{m} \pm 5.0$ for the uncoated moist particles and $241.9 \pm 7.5 \mu \mathrm{m}$ for the coated particles. These results show that the coating did not affect the particle size, although, there is a tendency to size increase after coating. Although, there are differences between the sizes of the particles freshly rehydrated and the moist ones (Table 1), there is a high rehydration rate meaning that placing the dried particle in aqueous systems will result in quick rehydration. This rapid rate of rehydration was previously observed in dry particles containing alginate or alginate-chitosan (POLK et al., 1994).

The sizes obtained are compatible with living foods commonly used to feed larvae ranging from 125 to $300 \mu \mathrm{m}$ in size, for rotifers such as the Brachionus plicatilis and from 350 to $517 \mu \mathrm{m}$ 
for the Artemia spp. (EMMERSON, 1984; YÚFERA, RODRIGUEZ \& LUBIÁN, 1984; GENODEPA, ZENG \& SOUTHGATE, 2004). Cahu \& Zambonino Infante (2001) used a 50-125 $\mu \mathrm{m}$ micro diet during the first larval stage; from day 14 to day 25 , the diets were increased to $125-200 \mu \mathrm{m}$, and 200$400 \mu \mathrm{m}$ thereafter until the $40^{\text {th }}$ day. Tang, Chen \& Wu (2010), used 150-250 $\mu \mathrm{m}$ micro diet from 1-9 days after the Cobia larvae eclosion (Rachycentron canadum). Particularly small diets ( $<50 \mu \mathrm{m}$ ) can not be easily detected by the larvae, whereas the ingestion of the large ones is difficult and can lead to blockage of the digestive system (WALFORD, LIM \& LAM, 1991).

\subsection{MORPHOLOGY}

The morphology of the particles when observed by light microscopy shows the formation of multi nucleated matrixes, with a defined and continuous wall around the microparticle (Figure 2). The lipid content was uniformly distributed in the pectin or alginate matrixes, showing the distribution of lipid droplets of different sizes along the length of the microparticle. The particles were, mostly spherical or approximately spherical. The light microscopy images indicated that both the moist (Figure $2 \mathrm{~A}$ to $2 \mathrm{E}$ ) and the rehydrated particles presented similar formation after rehydration (Figure $2 \mathrm{D}$ and $2 \mathrm{H}$ ). This effect was previously observed in dried particles produced by ionic gelation, which showed a considerable rehydration after contact with water (MUKAI-CORREA et al., 2005).
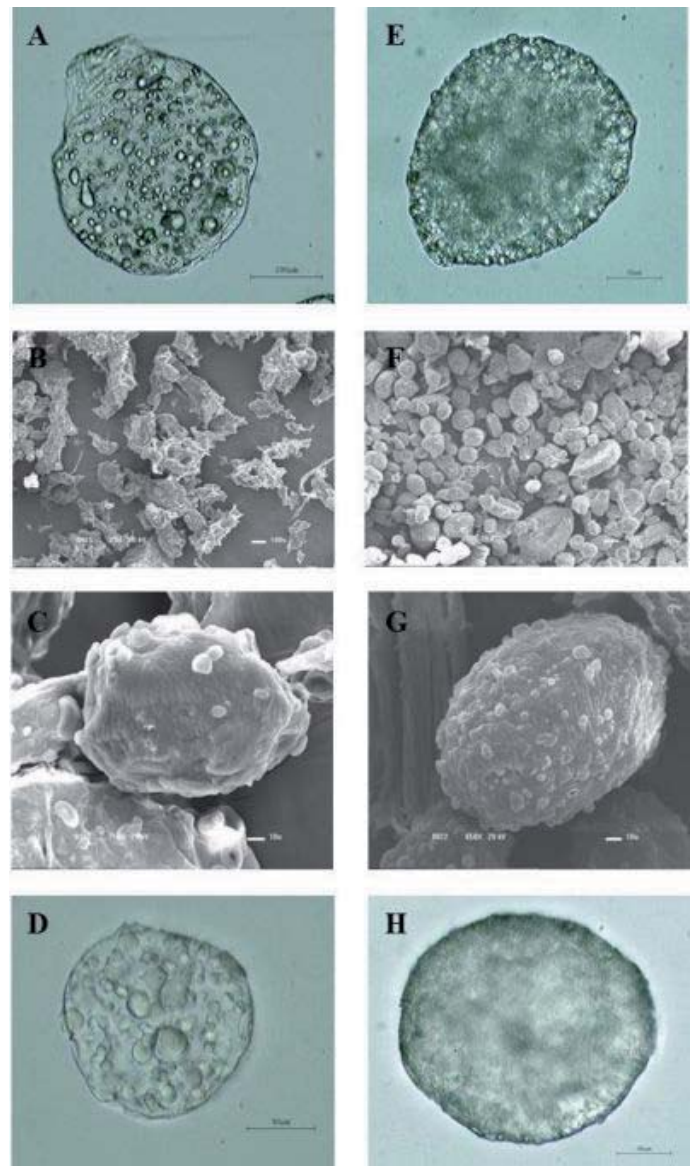

\footnotetext{
FIGURE 2 - MICROGRAPHS OF PEM PARTICLES (PARTICLES PRODUCED WITH PECTIN AND COATED WITH WPC) LOCATED IN THE LEFT COLUMN AND ALM PARTICLES (PARTICLES PRODUCED WITH ALGINATE AND COATED WPC) LOCATED IN THE RIGHT COLUMN. A AND E - MOIST PARTICLES, B, F, C AND G - FREEZE DRIED PARTICLES OBSERVED BY SCANNING ELECTRON MICROSCOPY, D AND H - REHYDRATED PARTICLES
} 
The microscopy of the dried particles using SEM (Figure 2C and Figure 2G) showed that the particles had similar form and remained partly intact after the drying process, having a spherical contour, with lipid droplets in the wall material. Agglomeration was observed between pectin particles (Figure 2B) after the freeze drying. This behavior is different from the alginate particles, which after freeze drying retained the spherical shape (Figure $2 \mathrm{~F}$ ) with whole and non-agglomerated particles. Despite the clustering observed, the pectin particles after rehydration regain a nearly spherical form, and with continuous walls without any cracking (Figure 2D and Figure $2 \mathrm{H}$ ).

\subsection{PROXIMATE COMPOSITION}

Table 2 shows the protein, lipid, ash and moisture contents of the particles produced by ionic gelation and after electrostatic interaction with the whey proteins. The averages of the protein, lipid, moisture and ash contents were not significantly different $(p>0.05)$ between treatments.

Rodrigues (2012) evaluated WPC coated particles with concentrations ranging from 4 to $12 \%$, observing no significant differences in the protein adsorption with WPC concentrations of 6 , 8 and $12 \%$, obtaining particles protein levels above $50 \%$. Furthermore, the average size of the particles increased with the rising protein concentration. In this study, the choice of the whey protein concentration used for coating the particles, was based on the possibility to obtain particles with high content of adsorbed protein associated with an appropriate size. The WPC $12 \%$ concentrations was chosen for the particles production, also considering that the Artemia nauplii average size are between 350-530 um (EMMERSON, 1984; YÚFERA, RODRIGUEZ \& LUBIÁN, 1984).

\section{TABLE 2 - PROXIMATE COMPOSITION OF THE PARTICLES PRODUCED BY IONIC GELATION, FOLLOWED BY ELECTROSTATIC INTERACTION WITH WHEY PROTEINS}

\begin{tabular}{|c|c|c|c|c|}
\hline \multirow{2}{*}{ Diets } & \multicolumn{4}{|c|}{ Proximate Composition \% (dry base) } \\
\hline & Moisture & Protein & Lipid & Ashes \\
\hline PEM & $85.49 \pm 0.59^{a^{*}}$ & $49.08 \pm 0.47^{a}$ & $21.22 \pm 0.65^{a}$ & $4.14 \pm 0.28^{a}$ \\
\hline ALM & $85.39 \pm 0.53^{a}$ & $49.01 \pm 0.60^{a}$ & $20.98 \pm 0.35^{a}$ & $4.26 \pm 0.14^{\mathrm{a}}$ \\
\hline
\end{tabular}

PEM = particles produced from pectin cover with WPC; $A L M=$ particles produced from alginate covered with WPC* . Means followed by same letters did not differ according to the Tukey test $(p>0.05)$.

Regardless the type of polysaccharide used, the particles showed high levels of protein adsorbed ( 50\%). In comparison with the Artemia nauplii proximate composition found in the literature (BASKERVILLE \& KLING, 2000) the two particles presented a similar protein composition. In previous studies seeking to mimic the Artemia nauplii, the attempt to incorporate the protein inside a microparticle produced using ionic gelation, was not met accordingly with respect to the microencapsulation efficiency (MUKAI-CORREA, 2008), reaching the maximum of $35 \%$ protein incorporation (dry basis).

The lipid contents in the PEM and the ALM particles (21\%) are similar to those found in the Artemia nauplii (BASKERVILLE \& KLING, 2000; RODRIGUES, 2012). Lipids are known for playing an important role in the feeding, providing the energy which supports the structural integrity of the biologic membranes and act as precursors of important steroids (CORRAZE, 2001). Diets formulated 
for sea bream and sole larvae contained from 18 and $25 \%$ lipids respectively, similar values to those usually found in live foods (SALHI et al., 1999; FURUITA, TAKEUCHI \& UEMATSU, 1998). The particles ash contents ( 4\%) were similar to that found in the Artemia nauplii and later found in the diet produced for pacu larvae feeding (RODRIGUES, 2012). The protein and lipid contents were similar to the microencapsulated diet developed by Chu \& Ozkizilcik (1999), which contained $53 \%$ of protein and $21 \%$ of lipids, respectively.

The diets moisture contents were comparable to the moisture contents observed for the Artemia, unlike the commercial and experimental diets, whose moisture content is quite low, averaging 10 \% (YÚFERA; PASCUAL \& FERNÁNDEZ-DIAZ, 1999; BASKERVILLE \& KLING, 2000; KVÅLE et al., 2006). This high moisture content can contribute to the better digestion of the diet, since the large amount of dry matter is one of the factors contributing for difficulty in the digestion of formulated diets (KOLKOVSKI, 2001).

All particles (Table 2) showed high levels of moisture (> $85.0 \%$ ), similar to the particles obtained by Mukai-Correa et al. (2005), which have shown moisture levels superior to $90 \%$. Such high values are characteristic of particles produced with gel forming polysaccharides, due to its high water retention capabilities. Moreover, the disadvantage of a high moisture content is a rapid deterioration of the microparticle; however all the particles remained intact after the freeze drying process that would minimize the moist particles short shelf life issue, besides the excellent rehydration capacity.

\section{CONCLUSION}

The results showed that the particles produced using ionic gelation followed by the electrostatic interaction with whey proteins, allowed for the production of particles with protein $(\sim 50 \%)$, lipid ( $\sim 20 \%)$ and moisture ( $\sim 5 \% \%)$ compositions, similar as found in the Artemia, using either low methoxyl amidated pectin or alginate with high contents of guluronic acid and whey proteins. The particles were partly spherical with homogeneous lipids distribution, average size ranging from $256.7 \mu \mathrm{m} \pm 17.1$ and $241.9 \mu \mathrm{m} \pm 7.5$ for pectin and alginate, respectively with no statistical difference, similar to the mean size of rotifers and close to the mean size of Artemia, both used for intensive rearing of fish larvae.

The incorporation of a high content of minerals and vitamins ( 4\%) produces a nutritionally balanced microparticle; therefore suitable as a partial replacement for the live food. Although, the composition is very similar to the live food, it becomes necessary to perform in vivo tests with fish larvae to evaluate the use of particles as artificial diet and, if necessary, their suitability.

RESUMO

\section{MIMETIZAÇÃO DE ALIMENTO VIVO DE LARVAS DE PEIXES COM PARTÍCULAS OBTIDAS POR GELIFICAÇÃO IÔNICA E RECOBERTAS COM PROTEÍNA POR INTERAÇÃO ELETROSTÁTICA}

$\mathrm{Na}$ tentativa de mimetizar a composição centesimal encontrada em náuplios de Artemia, alimentação comumente utilizada na criação intensiva de larvas de peixes, foram produzidas dietas inertes por gelificação iônica utilizando pectina de baixo teor de esterificação amidada ou alginato de sódio, posteriormente recobertas com proteínas de soro de leite por interação eletrostática. As partículas foram caracterizadas morfologicamente por microscopia ótica e microscopia eletrônica de varredura e apresentaram forma esférica quando úmidas ou reidratadas. As partículas após produção foram caracterizadas com relação a sua composição centesimal, tamanho médio e comportamento de reidratação após secagem por liofilização. Partículas de pectina e alginato recobertas apresentaram tamanhos médios de 256,7 $\mu \mathrm{m} \pm 17,1$ e 241,9 $\mu \mathrm{m} \pm 7,5$, respectivamente, sem diferença estatística. Em relação ao conteúdo lipídico, proteico, de matéria-seca e cinzas as partículas produzidas eram semelhantes ao alimento vivo. No entanto, avaliação in vivo com larvas de peixes torna-se necessária para confirmar a sua adequação e funcionalidade.

PALAVRAS-CHAVE: GELIFICAÇÃO IÔNICA; INTERAÇÃO ELETROSTÁTICA; PECTINA; ALGINATO; CONCENTRADO PROTEICO DE SORO DE LEITE; MICROPARTÍCULAS. 


\section{REFERENCES}

1 ALLAN-WOJTAS, P. M.; HANSEN, L. T.; CARBYN, S.; PAULSON, A. T. Microstructure of Ca-alginate microbeads with or without encapsulated Bifidobacterium lactis using cold-stage scanning electron microscopy. Scanning, v.21, n.1, p.118119, 1999.

2 ANAL, A.K.; STEVENS, W.F. Chitosan-alginate multilayer beads for controlled release of ampicillin. International Journal of Pharmaceutics, v.290, n.1-2, p.45-54, 2005.

3 AOAC. Association of Official Analytical Chemists. Official methods of analysis of AOAC International. $18^{\text {th }}$ ed. Washington, DC, 2006.

4 AUGUSTIN, M.A.; ABEYWARDENA, M.Y.; PATTEN, G.; HEAD, R.; LOCKETT, T.; DE LUCA, A.; SANGUANSRI, L. Effects of microencapsulation on the gastrointestinal transit and tissue distribution of a bioactive mixture of fish oil, tributyrin and resveratrol. Journal of Functional Foods, v.3, n.1, p.25-37, 2011.

5 BASKERVILLE, B.; KLING, L.J. Development and evaluation of microparticulate diets for early weaning of Atlantic cod Gadus morhua larvae. Aquaculture Nutrition, v.6, n.3, p.171-182, 2000.

6 BLIGH, E.G.; DYER, W.J. A rapid method of total lipid extraction and purification. Canadian Journal of Biochemistry and Physiology, v.37, n.8, p.911-917, 1959.

7 CAHU, C.; ZAMBONINO INFANTE, J. Substitution of live food by formulated diets in marine fish larvae. Aquaculture, v.200, n.1-2, p.161-180, 2001.

8 CHAN, L.W.; LEE, H.Y.; HENG, P.W.S. Production of alginate microspheres by internal gelation using an emulsification method. International Journal of Pharmaceutics, v.242, n.1-2, p.259-262, 2002.

9 CHANDRAMOULI, V.; KAILASAPATHY, K.; PEIRIS, P.; JONES, M. An improved method of microencapsulation and its evaluation to protect Lactobacillus spp. in simulated gastric conditions. Journal of Microbiological Methods, v.56, n.1, p.27-35, 2004

$10 \mathrm{CHU}$, F.-L.E.; OZKIZILCIK, S. Acceptability of complex microencapsulated diets by striped bass (Morone saxatilis) larvae. Journal of Experimental Marine Biology and Ecology, v.237, n.1, p.1-9, 1999.

11 CORRAZE, G. Lipid nutrition. In: NUTRITION and feeding of fish and crustaceans. Chichester, UK: Springer Prarois, 2001. p.111-130.

12 DAI, C.; WANG, B.; ZHAO, H. Microencapsulation peptide and protein drugs delivery system. Colloids and Surfaces B: Biointerfaces, v.41, n.2-3, p.117-120, 2005.

13 DZIEZAK, J.D. Microencapsulation and encapsulated ingredients. Food Technology, v.4, n. 4, p.136-151, 1988.

14 EMMERSON, W.D. Predation and energetics of Penaeus indicus (Decapoda: Penaeidae) larvae feeding on Brachionus plicatilis and Artemia nauplii. Aquaculture, v.38, n.3, p.201-209, 1984

15 FAO. Food and Agriculture Organization. Compendium of food additive specifications. Roma, 2009. p.75-80. (FAO JECFA Monographs, 7)

16 FURUITA, H.; KONISHI, K.; TAKEUCHI, T. Effect of different levels of eicosapentaenoic acid and docosahexaenoic acid in Artemia nauplii on growth, survival and salinity tolerance of larvae of Japanese flounder, Paralichthys olivaceus. Aquaculture, v. 170, p. 59-69, 1999.

17 GBASSI, G.K.; VANDAMME, T.; YOLOU, F. S.; MARCHIONI, E. In vitro effects of pH, bile salts and enzymes on the release and viability of encapsulated Lactobacillus plantarum strains in a gastrointestinal tract model. International Dairy Journal, v.21, n.2, p.97-102, 2011.

18 GENODEPA, J.; ZENG, C.; SOUTHGATE, P.C. Preliminary assessment of a microbound diet as an Artemia replacement for mud crab, Scylla serrata, megalopa. Aquaculture, v.236, n.1-4, p.497-509, 2004.

19 GOMBOTZ, W.R.; WEE, S. Protein release from alginate matrices. Advanced Drug Delivery Reviews, v.31, n.3, p.267285, 1998.

20 GUTHRIE, K.M.; RUST, M.B.; LANGDON, C.J.; BARROWS, F.T. Acceptability of various microparticulate diets to firstfeeding walleye Stizostedion vitreum larvae. Aquaculture Nutrition, v.6, n.3, p.153-158, 2000.

21 HAMLIN, H.J.; KLING, L.J. The culture and early weaning of larval haddock (Melanogrammus aeglefinus) using a microparticulate diet. Aquaculture, v.201, n.1-2, p.61-72, 2001.

22 HUGUET, M.L.; DELLACHERIE, E. Calcium alginate beads coated with chitosan: effect of the structure of encapsulated materials on their release. Process Biochemistry, v.31, n.8, p.745-751, 1996. 
23 KAILASAPATHY, K.; MASONDOLE, L. Survival of free and microencapsulated Lactobacillus acidophilus and Bifidobacterium lactis and their effect on texture of feta cheese. Australian Journal of Dairy Technology, v.60, n.3, p.48-54, 2003.

24 KOLKOVSKI, S. Digestive enzymes in fish larvae and juveniles - implications and applications to formulated diets. Aquaculture, v.200, n.1-2, p.181-201, 2001.

25 KVÅlE, A.; YÚFERA, M.; NYGÅRD, E.; AURSLAND, K.; HARBOE, T.; HAMRE, K. Leaching properties of three different micropaticulate diets and preference of the diets in cod (Gadus morhua L.) larvae. Aquaculture, v.251, n.2-4, p.402-415, 2006.

26 LANGDON, C. Microparticle types for delivering nutrients to marine fish larvae. Aquaculture, v.227, n.1-4, p.259-275, 2003

27 LISERRE, A.M; RÉ, M.I.; FRANCO, B.G.M. Microencapsulation of Bifidobacterium animalis subsp. lactis in modified alginate-chitosan beads and evaluation of survival in simulated gastrointestinal conditions. Food Biotechnology, v.21, n.1, p. 1-16, 2007.

28 LY, M. H.; AGUEDO, M.; GOUDOT, S.; LE, M. L.; CAYOT, P.; TEIXEIRA, J. A.; LE, T. M.; BELIN, J. M.; WACHÉ, Y. Interactions between bacterial surfaces and milk proteins, impact on food emulsions stability. Food Hydrocolloids, v.22, n.5, p.742-751, 2008.

29 MESTDAGH, M.M.; AXELOS, M.A.V. Physico-chemical properties of polycarboxylate gel phase and their incidence on the retention/release of solutes. Biopolymer Science: Food and Non-food Applications, v.91, n. 1, p.303-314, 1998.

30 MUKAI-CORREA, R. Produção de micropartículas por gelificação iônica para alimentação de larvas de peixe: estudos em sistema-modelo com inclusão de micropartículas lipídicas ou emulsão lipídica e testes in vivo. 2008117 f. Tese (Doutorado em Controle de Qualidade), Universidade Estadual de Campinas, Campinas, 2008.

31 MUKAI-CORREA, R.; PRATA, A.S.; ALVIM, I.; GROSSO, C. Caracterização de microcápsulas contendo caseína e gordura vegetal hidrogenada obtidas por gelificação iônica. Brazilian Journal of Food Technology, v.8, n.1, p.73-80, 2005.

32 MUKAI-CORREA, R.; PRATA, A. S.; ALVIM, I.D.; GROSSO, C.R. Controlled release of protein from hydrocolloid gel microbeads before and after drying. Current Drug Delivery, v.3, n.3, p.265-273, 2004.

33 PEPPAS, N.A; BRANNON-PEPPAS, L. Controlled release of fragrances from polymers I. Thermodynamic analysis. Journal of Controlled Release, v.40, n.3, p.245-250, 1996.

34 POLK, A.; AMSDEN, B.; DE YAO, K.; PENG, T.; GOOSEN, M.F.A. Controlled release of albumin from chitosan-alginate microcapsules. Journal of Pharmaceutical Sciences, v.83, n.2, p.178-185, 1994.

35 RALET, M.-C.; DRONNET, V.; BUCHHOLT, H.C.; THIBAULT, J.-F. Enzymatically and chemically de-esterified lime pectins: characterisation, polyelectrolyte behaviour and calcium binding properties. Carbohydrate Research, v.336, n.2, p.117125, 2001.

36 RODRIGUES, J.B. Desenvolvimento de micropartículas contendo Lactobacillus acidophilus para alimentação de larvas de pacu (Piaractus mesopotamicus). 2012. 132 f. Dissertação. (Mestrado em Nutrição Experimental aplicada a Tecnologia de Alimentos), Universidade Estadual de Campinas, Campinas, 2012.

37 SANTIPANICHWONG, R.; SUPHANTHARIKA, M.; WEISS, J.; MCCLEMENTS, D.J. Core-shell biopolymer nanoparticles produced by electrostatic deposition of beet pectin onto heat-denatured $\beta$-lactoglobulin aggregates. Journal of Food Science, v.73, n.6, p.N23-N30, 2008.

38 SALHI, M.; HERNANDEZ-CRUZ, C.M.; BESSONART, M.; IZQUIERDO, M.S.; FERNANDEZ-PALACIOS, H. Effect of different dietary polar lipid levels and different n-3 HUFA content in polar lipids on gut and liver histological structure of gilthead seabream (Sparus aurata) larvae. Aquaculture, v.179, p. 253-263, 1999.

39 SILVA, C.M.; RIBEIRO, A.J.; FIGUEIREDO, I.V.; GONÇALVES, A.R.; VEIGA, F. Alginate microspheres prepared by internal gelation: development and effect on insulin stability. International Journal of Pharmaceutics, v.311, n.1-2, p.110,2006

40 SIMSEK-EGE, F.A.; BOND, G.M.; STRINGER, J. Polyelectrolyte complex formation between alginate and chitosan as a function of pH. Journal of Applied Polymer Science, v.88, n.2, p.346-351, 2003.

41 SOUZA, F.N.; GEBARA, C.; RIBEIRO, M.C.E.; CHAVES, K.S.; GIGANTE, M.L.; GROSSO, C.R.F. Production and characterization of microparticles containing pectin and whey proteins. Food Research International, v.49, n.1, p. 560566, 2012.

42 TANG, B.G.; CHEN, G.; WU, Z.H. Application of a microdiet in cobia Rachycentron canadum (Linnaeus, 1766) larvae rearing. Aquaculture Research, v.41, n.2, p.315-320, 2010. 
43 WALFORD, J.; LIM, T.M.; LAM, T.J. Replacing live foods with microencapsulated diets in the rearing of seabass (Lates calcarifer) larvae: do the larvae ingest and digest protein-membrane microcapsules? Aquaculture, v.92, p.225-235, 1991.

44 WALKENSTRÖM, P.; HERMANSSON, A.-M. Mixed gels of gelatin and whey proteins, formed by combining temperature and high pressure. Food Hydrocolloids, v.11, n.4, p.457-470, 1997.

45 YÚFERA, M.; PASCUAL, E.; FERNÁNDEZ-DÍAZ, C. A highly efficient microencapsulated food for rearing early larvae of marine fish. Aquaculture, v.177, n.1-4, p.249-256, 1999.

46 YÚFERA, M.; RODRIGUEZ, A.; LUBIÁN, L. M. Zooplankton ingestion and feeding behavior of Penaeus kerathurus larvae reared in the laboratory. Aquaculture, v.42, n.3-4, p.217-224, 1984.

\section{ACKNOWLEDGMENTS}

The authors wish to thank the FMC Biopolymer (Sodium alginate, DMB, Manugel, Campinas, SP, Brazil), the CPKelco (low methoxyl amidated pectin, Limeira, São Paulo, Brazil) and the Fri-Ribe (mineral and vitamin mixture, Pitangueiras, São Paulo, Brazil). 